\title{
Studi Perencanaan Pembangunan Pembangkit Iistrik Tenaga Mikrohidro (PLTMH) Berdasarkan Potensi Air yang Ada di Desa Pinogu
}

\author{
Susanto Ointu \\ Program Studi Teknik Elektro \\ Universitas Ichsan Gorontalo \\ Gorontalo, Indonesia \\ santo.ointu@gmail.com
}

\author{
Frengki Eka Putra Surusa \\ Program Studi Teknik Elektro \\ Universitas Ichsan Gorontalo \\ Gorontalo, Indonesia \\ kiki.alaska@gmail.com
}

\author{
Muammar Zainuddin \\ Program Studi Teknik Elektro \\ Universitas Ichsan Gorontalo \\ Gorontalo, Indonesia \\ Muammarzainuddin@unisan.ac.id
}

Diterima : Februari 2020

Disetujui : Juni 2020

Dipublikasi : Juli 2020

\begin{abstract}
Abstrak-- Listrik merupakan kebutuhan yang sangat berperan penting bagi kehidupan manusia. Sehingga itu rencananya diwilayah terpencil tersebut akan diadakan pembangkit listrik yang ramah lingkungan, dan juga termasuk energi terbarukan. Kecamatan Pinogu terdapat bendungan untuk bisa dimanfaatkan sebagai sumber Pembangkit Listrik Tenaga Mikrohidro (PLTMH). Tujuan dari penelitian ini adalah untuk mengetahui seberapa besar potensi air untuk menghasilkan energi listrik pada bendungan yang dapat menunjang elektrifikasi di Desa Pinogu Kecamatan Pinogu Kabupaten Bone Bolango. Metode yang digunakan dalam menghitung debit air pada bendungan tersebut dengan metode apung dan pengukuran menggunakan stopwatch. Berdasarkan hasil pengukuran pada lokasi bendungan di Desa Pinogu Kecamatan Kabupaten Bone Bolango, menghasilkan potensi air dengan debit air maksimal sebesar $1,67 \mathrm{m3} /$ detik, dengan tinggi terjun 3,57 meter, maka total daya maksimal yang diperoleh adalah $29,83 \mathrm{KW}$ dan dapat melayani 99 rumah dengan daya masing-masing rumah sebesar 300 Watt.
\end{abstract}

Kata Kunci — studi kelayakan, PLTM, Desa Pinogu.

Abstract-- Electricity is a necessity that plays an important role in human life. So that the plan is in the remote region will be held power plants that are environmentally friendly, and also include renewable energy. Pinogu Subdistrict has a dam to be used as a source of Micro Hydro Power Plant (PLTMH). The purpose of this study is to find out how much the potential of water to produce electrical energy in dams that can support electrification in Pinogu Village, Pinogu District, Bone Bolango Regency. The method used in calculating the flow of water in the dam with the floating method and measurement using a stopwatch. Based on the results of measurements at the location of the dam in Pinogu Village, District of Bone Bolango District, it produces water potential with a maximum water discharge of $1.67 \mathrm{m3} / \mathrm{sec}$, with a waterfall height of 3.57 meters, then the total maximum power obtained is $29.83 \mathrm{KW}$ and can serves 99 homes with a power of 300 Watt each.

Keywords - feasibility study, PLTM, Pinogu Village.

\section{PENDAHULUAN}

Di Era modern seperti saat ini, listrik merupakan kebutuhan yang sangat berperan penting bagi kehidupan manusia. Di Indonesia pemasok energi listrik paling besar adalah Perusahaan Listrik Negara (PLN). Energi listrik saat ini belum sepenuhnya dinikmati atau digunakan oleh sebagian masyarakat didaerah terpencil [1]. Hal ini disebabkan oleh beberapa faktor yaitu faktor kondisi alam, jalan yang sulit dijangkau dan kondisi perumahan penduduk yang tidak berbentuk sebuah desa atau dengan kata lain jarak rumah penduduk yang satu dengan yang lainya cukup jauh [2]. Untuk itu diperlukan suatu kebijakan energi yang berkelanjutan dengan memperluas akses kecakupan pasokan energi yang handal dan terjangkau dengan memperhatikan sarana dan prasarana yang diperlukan dan dampak lingkungan yang ditimbulkan seperti pencemaran udara [3]. Sehingga rencananya diwilayah terpencil tersebut akan direncanakan pembangunan pembangkit listrik yang ramah lingkungan, dan juga termasuk sebagai energi terbarukan yaitu Pembangkit Listrik Tenaga Mikrohidro (PLTMH) sebagai sumber pasokan energi listrik. Pengunaan PLTMH banyak sumbangan yang sangat berarti dalam penghematan energi, selain itu juga berkonstribusi terhadap perbaikan mutu lingkungan hidup [4].

Desa Pinogu Kecamatan Pinogu Kabupaten Bone Bolango Provinsi Gorontalo merupakan desa yang terisolir. Desa tersebut saat ini belum terdapat jaringan listrik PLN dan sulit dijangkau oleh kenderaan umum. Dalam penggunaan akan energi listrik yang ada di Desa tersebut, masyarakat masih menggunakan energi listrik matahari (PLTS) secara mandiri [5]. Oleh kerena itu perlu adanya pemanfaatan energi listrik baru dan terbarukan. Mengingat Desa Pinogu terletak pada kontur dataran tinggi, dan terdapat beberapa aliran sungai yang besar maka perlu 
memanfaatkan energi air tersebut untuk dijadikan sumber energy listrik.

Saat ini di Desa Pinogu telah dibangun suatu bendungan air yang cukup besar. Dengan memanfaatkan adanya bendungan air tersebut, dianggap perlu untuk dijadikan suatu sumber energi listrik. sehingga dilakukan studi perancanaan Pembangkit Listrik Tenaga Mikrohidro (PLTMH) dengan memanfaatkan potensi air sungai Pinogu. Dengan adanya studi perencanaan pembangunan PLTMH tersebut maka dilakukan penelitian tentang analisis potensi air sungai yang bisa dimanfaatkan bagi masyarakat desa Pinogu sebagai sumber energi listrik.

\section{Tinjauan Pustaka}

\section{Pembangkit}

Khusus di Indonesia pemanfaatan potensi energi terbarukan seperti air, angin, biomassa, dan lainnya sampai saat ini belum optimal. Misalnya untuk kasus energi air hanya mencapai 4.200 MW dari 75,67 GW potensi yang ada atau hanya 5,55\% [2]. Seperti terlihat pada Tabel 1.

Tabel 1. Potensi energi terbarukan di Indonesia

\begin{tabular}{|c|c|c|c|}
\hline $\begin{array}{c}\text { Sumber } \\
\text { Energi }\end{array}$ & $\begin{array}{c}\text { Potensi } \\
\text { (MW) }\end{array}$ & $\begin{array}{c}\text { Kapasitas } \\
\text { Terpasang }\end{array}$ & Pemanfaatan \\
\hline Air & 75.670 & 4.200 & 5,55 \\
\hline Biomassa & 49.810 & 302,4 & 0.607 \\
\hline Panas Bumi & & 800 & 2,9 \\
\hline $\begin{array}{c}\text { Mini/Mikro } \\
\text { hidro }\end{array}$ & 458.75 & 84 & 18,3 \\
\hline $\begin{array}{c}\text { Energi } \\
\text { Cahaya }\end{array}$ & 156.487 & 8 & 0,005 \\
\hline $\begin{array}{c}\text { Energi } \\
\text { Angin }\end{array}$ & 9.280 & 0,5 & 0,005 \\
\hline Total & $\mathbf{3 1 8}$ & $\mathbf{5 . 3 9 1 , 9 0}$ & $\mathbf{2 7 , 4 2 7}$ \\
\hline
\end{tabular}

(Sumber: Blueprint Pengelolaan Energi Nasional 20052025)

\section{Kondisi Geografis Dan Potensi Energi Terbarukan}

Kabupaten Bone Bolango merupakan salah satu kabupaten di Provinsi Gorontalo, secarageografis mempunyai luas $1.984,58 \mathrm{~km}^{2}$ atau $16,24 \%$ dari luas total Provinsi Gorontalo. Kabupaten Bone Bolango dibagi menjadi 18 kecamatan, terdiri dari 166 kelurahan/desa. Kecamatan dengan luas terbesar adalah Kecamatan Suwawa Timur sedangkan kecamatan dengan luas daerah terkecil yaitu Kecamatan Bulango Selatan. Kecamatan Pinogu mempunyai sungai besar yang dapat dimanfaatkan potensi airnya untuk Pembangkit Listrik Tenaga Mikrohidro (PLTMH). Berdasarkan potensi geografinya Kabupaten Bone Bolango berbatasan langsung dengan Kabupatan Bolaang Mongondow Utara, sebelah selatan berbatasan dengan Kabupaten Bolaang Mongondow selatan dan teluk Tomini [2].

\section{Keunggulan PLTMH}

Sifat dari energi PLTMH ini adalah tak terhabiskan atau terbarukan dengan keunggulan antara lain PLTMH biasa beroperasi sehari penuh kerena air tidak tergantung siang dan malam, Pengoperasian PLTMH tidak memerlukan biaya yang mahal, serta beberapa keunggulan lainnya [2].

\section{Pengukuran}

A. Pengukuran Debit Air

Debit air merupakan jumlah air yang mengalir di dalam saluran atau saluran per unit waktu. Metode yang umum diterapkan seperti persamaan 1 untuk penetapan debit sungai adalah metode profil sungai (cross section)[6].

$$
Q=A \cdot V
$$

Dimana:

$\mathrm{Q}=$ Debit Aliran $\left[\mathrm{m}^{3} / \mathrm{s}\right]$

$\mathrm{A}=$ Luas Penampang Vertikal $\left[\mathrm{m}^{2}\right]$

$\mathrm{V}=$ Kecepatan Aliran Sungai $[\mathrm{m} / \mathrm{s}]$

\section{B. Luas Penampang}

Luas penampang diukur dengan menggunakan meteran dan piskal (tongkat bambu atau kayu) dan kecepatan aliran diukur dengan menggunakan "current meter" atau juga dengan metode apung. Untuk menghitung luas penampang dapat dihitung dengan persamaan 2 .

$$
\begin{aligned}
& A=L \times H \\
& \text { Dimana: } \\
& \text { A }=\text { Luas penampang basah }\left(\mathrm{m}^{2}\right) \\
& \mathrm{L}=\text { Lebar saluran }(\mathrm{m}) \\
& \mathrm{H}=\operatorname{Ketinggian} \text { saluran }(\mathrm{m})
\end{aligned}
$$

\section{Kecepatan Aliran}

Pengukuran kecepatan aliran dengan metode apung dilakukan dengan jalan mengapungkan suatu benda misalnya bola tenis atau botol bekas dapat dirumuskan persamaan 3 dan untuk factor koreksi untuk tiap jenis saluran diperlihatkan pada Tabel 2 .

$$
\begin{aligned}
& V=\frac{L}{t} \times c \\
& \text { Dimana: } \\
& \mathrm{V}=\text { Kecepatan }[\mathrm{m} / \mathrm{s}] \\
& \mathrm{L}=\text { Panjang Lintasan }[\mathrm{m}] \\
& \mathrm{t}=\text { Waktu Tempuh }[\mathrm{s}] \\
& \mathrm{c}=\text { Faktor Koreksi }(0.85)
\end{aligned}
$$

Tabel 2. Faktor Koreksi Untuk Tiap Jenis Saluran

\begin{tabular}{|c|c|}
\hline Jenis Beton & $\begin{array}{c}\text { Faktor } \\
\text { Koreksi }\end{array}$ \\
\hline Saluran Beton, persegi Panjang mulus & 0.85 \\
\hline Sungai luas, tenang, aliran bebas $\left(\mathrm{A}>10 \mathrm{~m}^{2}\right)$ & 0.75 \\
\hline Sungai dangkal, aliran bebas $\left(\mathrm{A}<10 \mathrm{~m}^{2}\right)$ & 0.65 \\
\hline Dangkal $(<0.5 \mathrm{~m})$, aliran turbulen & 0.45 \\
\hline Sangat dangkal $(<0.2 \mathrm{~m})$, aliran turbulen & 0.25 \\
\hline
\end{tabular}

\section{Pengukuran Tinggi Jatuh Air}

Penentuan debit dan head mempunyai arti yang sangat penting dalam menghitung potensi tenaga listrik. seperti pada Gambar 1. Variabel debit "diwakili” oleh jumlah ratarata bulan kering dalam satu tahun [7]. 


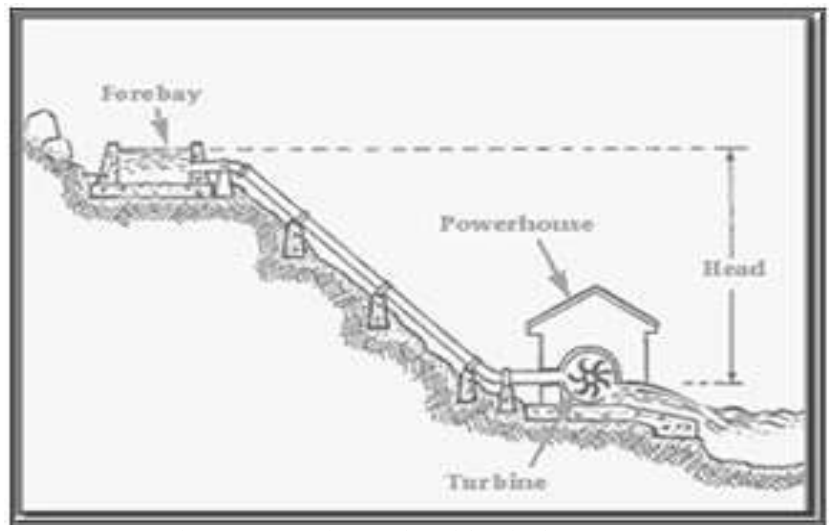

Gambar 1. Pengukuran tinggi jatuh air

Cara untuk mencari Head effectif menggunakan persamaan 4.

$$
\begin{aligned}
& H_{l}=H_{a}-H l \times e f f \\
& H_{l}=\ldots \ldots(m) \\
& H_{l}=H_{l} \times e f f \\
& H_{e}=m
\end{aligned}
$$

Adapun cara untuk menghitung Head Losses menggunakan persamaan 5 .

$$
H_{l}=0,02 \times \frac{L}{D} \times \frac{v^{2}}{2 \times 9,81}
$$

Diman:

$$
\begin{aligned}
& H_{l}=\text { Head losses }(\mathrm{m}) \\
& 0,02=\text { Faktor koreksi }(\%) \\
& \mathrm{L}=\text { Panjang pipa }(\mathrm{m}) \\
& \mathrm{D}=\text { Diameter pipa }(\mathrm{m}) \\
& \mathrm{V}^{2}=\text { Kecepatan aliran } \mathrm{m} / \text { detik } \\
& 9,81=\text { Konstanta gravitasi } \mathrm{m} / \mathrm{d}
\end{aligned}
$$

\section{Perencanaan Pembangkit Listrik Tenaga Mikro Hidro}

A. Penstock

Diameter pipa penstock ditentukan berdasarkan debit aliran yang akan mengalir pada pipa penstock tersebut dimana dalam penentuan diameter pipa penstock tersebut mempertimbangkan beberapa hal yakni keamanan, kemudahan proses pembuatan, ketersediaan material, tingkat rugi - rugi yang seminimal mungkin dan nilai ekonomis dari pipa penstock tersebut, dimana pipa yang memiliki diameter lebih besar memiliki tingkat rugi-rugi yang lebih minim dikarenakan kecepatan aliran air lebih kecil namun pipa pia penstock dengan ukuran diameter yang lebih besar ukurannya sangat besar, berat dan harganya lebih tinggi.

Adapun menentukan kecepatan aliran pada pipa PVC (pipa penstock) menggunakan persamaan 6 .

$$
A=1 / 4 \pi d^{2}
$$

dimana:

$$
\begin{aligned}
A & =\text { Kecepatan aliran dalam pipa } \\
d^{2} & =\text { Diameter pipa }
\end{aligned}
$$

Adapun cara mencari kecepatan pada pipa pesat yang Pipa pesat menggunakan pipa besi dengan panjang $9 \mathrm{~m}$ yang terbagi menjadi dua ukuran luas penampang yang berbeda menggunakan persamaan 7 .

$$
\begin{aligned}
& A_{1}=1 / 4 \times 3,14 \times(0,28)^{2} \\
& A_{1}=0,062 \mathrm{~m}^{2} \\
& V_{1}=\frac{1,69}{0,062} \\
& V_{1}=27,460 \mathrm{~m} / \mathrm{d}
\end{aligned}
$$

\section{B. Kincir Air/Turbin}

Berdasarkan spesifikasi teknis kincir air dan mempertimbangkan ketersediaan kincir air yang sudah ada maka dipilih jenis breast-shot sebagai desain pembangunan menggunakan persamaan 8

$$
N_{t}=\frac{862 \times H_{1}^{1 / 2}}{D_{1}}
$$

Dimana:

$$
\begin{gathered}
\mathrm{N}_{\mathrm{t}}=\text { Putaran kincir }(\mathrm{rpm}) \\
862=\text { Ketetapan rumus } \\
\mathrm{H}=\text { Tinggi jatuh }(\mathrm{m}) \\
\mathrm{D}_{1}=\text { Diameter pipa }(\mathrm{m})
\end{gathered}
$$

\section{Potensi Daya Terbangkitkan}

Kapasitas debit air mempengaruhi terhadap kapasitas daya listrik yang mampu dihasilkan oleh PLTMH. Untuk mencari potensi daya terbangkitkan dengan menggunakan batas efisiensi terendah adalah seperti pada persamaan 9 [8].

$$
\begin{aligned}
& \text { daya }(\mathrm{P})=9.81 \times \mathrm{Q} \times \mathrm{H} \times \eta_{\mathrm{p}} \times \eta_{\mathrm{t}} \times \eta_{\mathrm{g}} \\
& \text { Dengan: } \\
& \mathrm{P}=\text { Daya }(\mathrm{W}) \\
& 9.81=\text { Konstanta gravitasi } \\
& \mathrm{Q}=\text { Debit aliran }\left(\mathrm{m}^{3} / \mathrm{s}\right) \\
& \mathrm{H}=\text { Head }(\mathrm{m}) \\
& \eta_{\mathrm{p}}=\text { Efisiensi pipa } 90 \% \\
& \eta_{\mathrm{t}}=\text { Efisiensi turbin } 70 \% \\
& \eta_{\mathrm{g}}=\text { Efisiensi generator } 80 \%
\end{aligned}
$$

\section{Transmisi Mekanik}

Transmisi mekanik berfungsi untuk menyalurkan daya mekanik pada poros turbin ke poros generator tipe flat belt pulley dengan kombinasi plummer blockflexible coupling pada pulley generator. Adapun pemilihan jenis transmisi mekanik berdasarkan data sheet atau katalog turbin crossflow T-15 D500, untuk debit air dan head egektif pembangkit tersebut.

\section{Metode}

\section{Kerangka Konsep Penelitian}

Dalam sebuah perencanaan sistem tenaga listrik umumnya terdapat tiga komponen utama yang berperan penting dalam penyediaan energi listrik, komponen tersebut terdiri dari pembangkit listrik, saluran transmisi \& gardu induk dan bagian distribusi. Ketersediaan sumber daya alam merupakan salah satu faktor utama dalam penyediaan energy listrik. Pembangkit listrik Tenaga Mikrohidro merupakan pembangkit yang memanfaatkan potensi air dalam membangkitkan energy listrik. Seperti kita ketahui energy air merupakan sumber daya alam yang melimpah. Berdasarkan kondisi terebut maka dilakukan penelitian denga focus riset untuk memberikan gambaran dan informasi awal mengenai potensi air sebagai dasar dalam perencanaan dan pembangunan PLTMH. 


\section{Objek Penelitian/Alat dan Bahan}

Objek yang diteliti adalah tentang Studi Kelayakan potensi air untuk Pembangkit Listrik Tenaga Mikro Hidro (PLTMH),

Alat Dan Bahan Yang Digunakan:

1. Selang plastik transparan ukuran ${ }^{1 / 4}$ ukuran panjang 10 20 meter plastik ukuran ${ }^{1 / 4}$ ukuran 10-20 meter

2. Mistar ukur dan meteran

3. Pelampung plastik

4. Alat tulis

5. Asisten untuk membantu pengukuran

\section{Lokasi Penelitian}

Penelitian ini dilakukan di Desa Pinogu Kecamatan Pinogu. Berdasarkan data yang di peroleh dari pemerintah Kecamatan Pinogu, terdiri dari beberapa desa yaitu Desa Dataran Hijau, Desa Pinogu, Desa Tilonggibila, Desa Permai Dan Desa Baangio dengan jumlah penduduk keseluruhan \pm 1.390 Jiwa dan jumlah rumah Penduduk \pm 520 rumah dengan menggunakan sumber energi listrik dari Pembangkit Listrik Tenaga Surya ( PLTS Terpusat ) dengan daya masing-masing rumah 300 Watt itupun belum bisa mencukupi kebutuhan energi masyarakat pinogu karena pemakaian energi listrik melebihi kapasitas daya yang ada di setiap rumah. Titik kooordinat rencana pembangunan PLTMH adalah $0^{\circ} 31^{\prime} 10.0^{\prime \prime} \mathrm{N}$ dan 123'25'30.0'E., 0.519444, 123.42500. Peta Desa pinogu dan titik lokasi rencana pembangunan Pembangkit Listrik Tenaga Mikrohidro dapat dilihat pada Gambar 2.

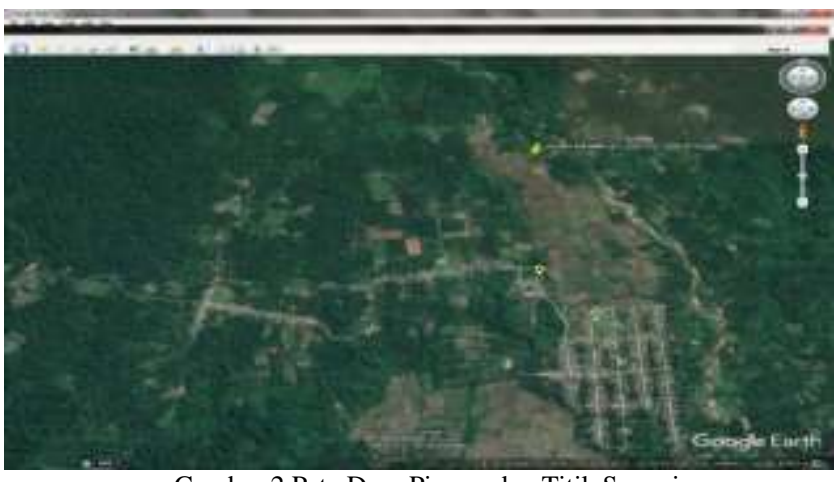

Gambar 2 Peta Desa Pinogu dan Titik Sungai

\section{Tahapan Alur Penelitian}

\section{A. Survei Lokasi}

Survei lokasi dilakukan untuk memperoleh data-data dan informasi primer terkait dengan aspek lokasi pembangunan PLTMH.

\section{B. Pengukuran dan Pengambilan Data}

1. Kecepatan Aliran

Metode sederhana untuk mengukur kecepatan aliran air adalah dengan menggunakan alat apung. Kecepatan aliran air adalah hasil pembagian jarak dengan waktu tempuh alat apung mengikuti aliran air. Kekasaran dasar sungai harus diperhitungkan dalam metode ini. Oleh karena itu kecepatan yang dihitung berdasarkan jarak dan waktu tempuh dan perlu dikoreksi dengan factor kekasaran sungai.

2. Luas Penampang sungai Pengukuran luas penampang basah disaat sungai tidak dalam keadaan banjir yaitu sesudah atau sebelum banjir. Pengukuran paling lambat dua penampang melintang yaitu di hulu dan di hilir yang merupakan titik awal dan titik ahir lintasan penampang. Luas penampang didapat dengan cara merata-ratakan luas kedua penampang basah yang telah diukur. Luas penampang basah sungai adalah penampang vertical sungai yang terisi air. Perhitungan luas penampang basah tersebut bergantung pada ketinggian air sungai saat itu terhadap profil sungai yang telah dibuat sebelumnya.

3. Pengukuran Debit Air

Maksud dan metode ini adalah untuk mengetahui apakah debit air yang tersedia mampu untuk menggerakkan turbin sesuai degan daya yang diinginkan. Debit air dihiutng berdasarkan perkalian antara luas penampang basah sungai dengan kecepatan aliran air.

4. Tinggi Jatuh Air

Tinggi jatuh air dapat diperoleh dengan mengurangi tinggi jatuh total dari permukaan air sampai pada permukaan air saluran bawah dengan kehilangan tinggi pada saluran air. Tinggi jatuh penuh adalah tinggi air yang bekerja efektif pada turbin yag sedang berjalan.

5. Efisiensi Turbin dan Generator

Jenis turbin yang digunakan adalah turbin crossflow kerena konstruksinya lebih sederhana, ukurannya kecil dan lebih mudah dalam proses pembuatannya. Sedangkan rencana generator yang digunakan dalam PLTMH ini adalah generator sinkron dengan merk Marelli Generator dengan Type MJB 250 MA4.

\section{Analisis Potensi Daya Terbangkitkan}

Potensi daya terbangkitkan tergantung pada hasil pengukuran debit air yang dihasilkan. Apabila debit air yang dihasilkan cukup besar maka potensi daya yang dihasilkan sangat besar. Tapi kalau sudah menggunakan batas efisiensi tertinggi maka potensi daya yang dihasilkan berkurang.

\section{Kelayakan}

Kelayakan suatu pembangkit tergantung pada kapasitas daya terbangkitkan, apabila dalam penelitian ini tidak sesuai dengan kapasitas daya terbangkitkan maka kembali lagi ke survey lokasi, begitupun sebaliknya apabila kapasitas daya terbangkikan sesuai dengan yang diharapkan maka penelitian ini dilanjutkan sampai dengan hasil penelitian, seperti terlihat pada Gambar 3 diagram alir penelitian. 


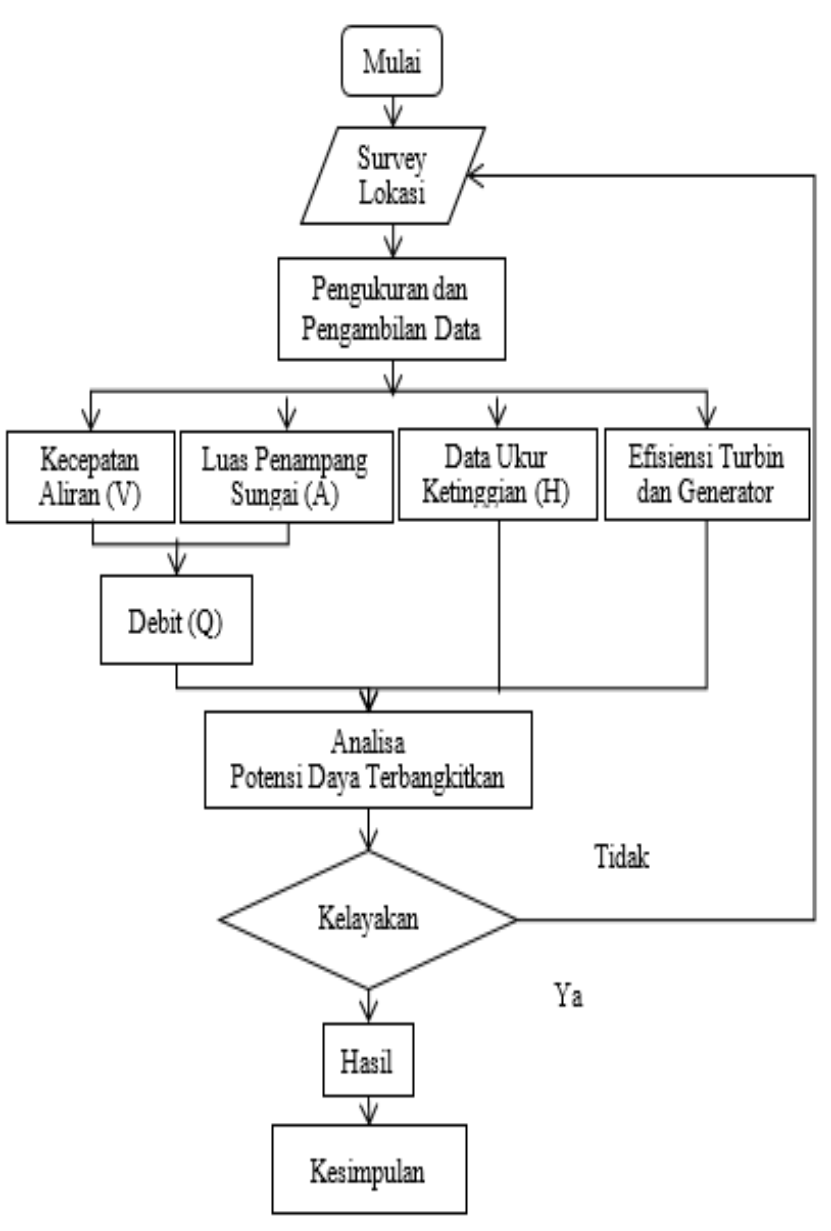

Gambar 3. Flowchart Penelitian

\section{Hasil dan Pembahasan}

\section{Pengumpulan Data}

Berdasarkan data yang dikumpulkan dari hasil penelitian maka langkah-langkah yang dilakukan sebagai berikut:

\section{A. Kondisi Geografis}

Berdasarkan posisi geografisnya, Kecamatan Pinogu memiliki batas-batas: Utara - Kabupaten Bolaang Mongondow utara Provinsi Sulawesi Utara; Selatan Kecamatan Bone Raya dan Kecamatan Bone; Barat Kecamatan - Suwawa Timur; Timur - Kabupaten Bolaang Mongondow Selatan Provinsi Sulawesi Utara.

Kecamatan Pinogu terdiri dari 5 Desa yaitu:

1. Desa Pinogu

2. Desa Bangio

3. Desa Pinogu Permai

4. Desa Dataran Hijau

5. Desa Tilonggibila

Luas Kecamatan Pinogu secara keseluruhan adalah $405.96 \mathrm{~km}^{2}$. Jika dibandingkan dengan wilayah Kabupaten Bone Bolango, luas Kecamatan ini sebesar $20.5 \%$. Sedangkan Desa terluas di Kecamatan Pinogu adalah Desa Bangio dan Desa yang memiliki luas terkecil adalah Desa Tilonggibila, seperti terlihat pada Gambar 4. Grafik persentase luas daerah menurut desa Kecamatan Pinogu dan Tabel 3. Luas wilayah dan persentase terhadap luas kecamatan menurut desa di Kecamatan Pinogu

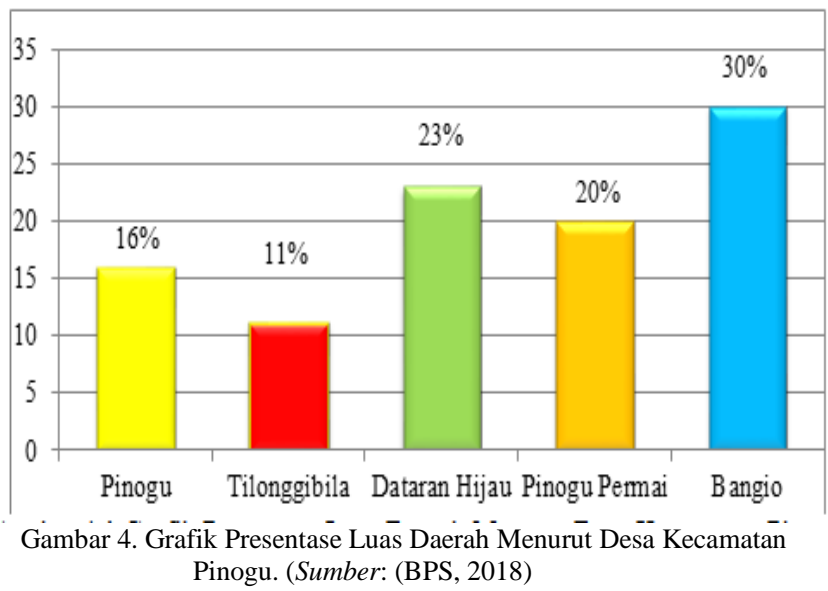

Tabel 3. Luas Wilayah dan Presentase terhadap Luas Kecamatan Menurut Desa di Kecamtan Pinogu, 2016

\begin{tabular}{|c|c|c|c|}
\hline No & Desa & $\begin{array}{c}\text { Luas } \\
\text { Wilayah } \\
\left(\mathrm{km}^{2}\right)\end{array}$ & $\begin{array}{c}\text { Presentase } \\
\text { Terhadap Luas } \\
\text { Kecamatan }\end{array}$ \\
\hline 1 & Pinogu & 64,24 & 16,07 \\
\hline 2 & Bangio & 120,4 & 29,63 \\
\hline 3 & Pinogu Permai & 82,68 & 20,37 \\
\hline 4 & Dataran Hijau & 92,2 & 22,72 \\
\hline 5 & Tilonggibila & 45,44 & 11,19 \\
\hline \multicolumn{2}{|c|}{ Kecamatan Pinogu } & 405,96 & 100 \\
\hline
\end{tabular}

B. Kondisi Topografi

Kondisi topografi dan kemiringan lereng di Kabupaten Bone Bolango cukup bervariasi dengan kelas lereng datar dengan kemiringan lereng $15-25 \%$, disusul oleh kelas kemiringan lereng $25-40 \%$ dan kelas-kelas lereng lainnya. Secara umum kondisi topografi wilayah Kabupaten Bone Bolango dikelompokkan ke dalam 3 kelompok yaitu kondisi tanah dengan permukaan tinggi (bergunung) atau tergantung pada kemiringan lereng diatas $40 \%$ dan bertekstur morfologi yang kasar.

\section{Hasil Pengukuran dan Perhitungan Debit Air}

Hasil Pengukuran dan perhitungan debit air berdasarkan perkalian antara luas penampang. Namun demikian, debit yang dihitung ini merupakan debit aliran saat itu (debit sesaat). Perhitungan debit air ini menggunakan nilai koefisien dasar sungai berbatu dan berpasir $(\mathrm{K}=0.85)$

\section{A. Kecepatan Aliran Sungai}

Pengukuran kecepatan aliran sungai yang memanfaatkan botol aqua bekas sebagai alat bantu. Kecepatan yang dihitung berdasarkan jarak dan waktu tempuh (kecepatan maksimal) perlu dikoreksi dengan faktor kekasaran sungai. Kekasaran sungai harus diperhitungkan dalam metode ini. Pengukuran kecepatan aliran air dilakukan selama 7 hari, dengan membagi lebar sungi menjadi 5 titik yaitu, tepi kanan sungai, antara tengah dan tepi kanan sungai, tengah sungai, antara tepi kiri dan tengah sungai dan tepi kiri sungai, sehingga didapat pengukuran rata-rata. Hasil pengukuran kecepatan aliran sungai pada bagian tepi kanan sungai dapat dilihat pada Tabel 4. Pengukuran Kecepatan Aliran Sungai. 
Tabel 4.Ppengukuran Kecepatan Aliran Sungai

\begin{tabular}{|c|c|c|c|c|}
\hline Tepi & $\begin{array}{c}\text { Faktor } \\
\text { Koreksi }\end{array}$ & $\begin{array}{c}\text { Kecepatan } \\
\text { aliran } \\
(\mathrm{m} / \mathrm{d})\end{array}$ & $\begin{array}{c}\text { Kecepatan } \\
\text { rata-rata } \\
\text { seluruhnya }\end{array}$ & $\begin{array}{c}\text { Kecepatan } \\
\text { rata-rata } \\
\text { terkoreksi }\end{array}$ \\
\hline 1 & 0,85 & 0,187 & & \multirow{2}{*}{0,204} \\
\cline { 1 - 3 } 2 & 0,85 & 0,173 & \multirow{2}{*}{0,173} \\
\hline 3 & 0,85 & 0,226 & & \\
\hline 4 & 0,85 & 0,195 & & \\
\hline 5 & 0,85 & 0,239 & & \\
\hline
\end{tabular}

Dari Tabel 4 terlihat bahwa kecepatan aliran sungai tertinggi pada hasil pengukuran keseluruhan terdapat pada tepi kiri sungai adalah sebesar 0,239 $\mathrm{m} /$ detik, dengan panjang lintasan 5 meter. Sedangkan pengukuran kecepatan aliran sungai terendah terdapat pada antara tepi kanan sungai dan tengah sungai sebesar $0,173 \mathrm{~m} /$ detik. Sehingga dalam perhitungan untuk mencarai hasil kecepatan rata-rata seluruhnya adalah dengan menggunakan persamaan 3 yaitu :

$$
\begin{aligned}
V & =\frac{v}{t} \times c \\
& =0,204 \mathrm{~m} / d \\
& =0,204 \times 0,85 \\
& =0,173 \mathrm{~m} / \mathrm{d}
\end{aligned}
$$

Jadi kecepatan rata-rata aliran sungai dari hasil perhitungan adalah sebesar 0,204 $\mathrm{m}$ /detik dikali dengan faktor koreksi $(\mathrm{K}=0,85)$. Maka hasil kecepatan rata-rata terkoreksi adalah $0,173 \mathrm{~m} /$ detik.

\section{B. Luas Penampang Sungai}

Luas penampang sungai di ukur dengan mengamati lebar sungai dan kedalaman air sungai. Profil sungai adalah mengukur kedalaman air pada setiap interval sungai dan hasilnya diperoleh dengan membagi lebar sungai menjadi 5 bagian (interval), dengan jarak interval masing-masing berukuran 5 meter.

Hasil pengamatan dan perhitungan luas penampang (m2) dapat diketahui dengan cara mengalikan hasil pengukuran kedalaman basah sungai dengan jarak interval sungai. Maka dapat diketahui luas penampang aliran sungai dengan menggunakan persamaan 2 sebagai berikut:

$$
\begin{aligned}
& A=L . H \\
& A=1,95 \times 5 m \\
& A=9,76 \mathrm{~m}^{2}
\end{aligned}
$$

Jadi hasil rata-rata pengukuran luas penampang sungai,

\begin{tabular}{|c|c|c|c|c|}
\hline $\begin{array}{l}\text { Hari } \\
\text { Ke- }\end{array}$ & $\begin{array}{l}\text { Lebar } \\
\text { Sungai } \\
\text { (meter) }\end{array}$ & $\begin{array}{c}\text { L (Jarak } \\
\text { Interval, } \\
\text { meter) }\end{array}$ & $\begin{array}{l}\text { D (Kedalaman } \\
\text { Basah, meter) }\end{array}$ & $\begin{array}{c}\mathrm{L} \times \mathrm{D} \\
\left(\mathrm{m}^{2}\right)\end{array}$ \\
\hline 1 & \multirow{7}{*}{25} & 5 & 1,94 & 9,7 \\
\hline 2 & & 5 & 1,90 & 9,5 \\
\hline 3 & & 5 & 2,03 & 10,15 \\
\hline 4 & & 5 & 2 & 10 \\
\hline 5 & & 5 & 1,96 & 9,8 \\
\hline 6 & & 5 & 1,93 & 9,65 \\
\hline 7 & & 5 & 1,91 & 9,55 \\
\hline
\end{tabular}
diketahui dengan cara mengalikan antara rata -rata pengukuran kedalaman basah sungai (1,95 m) dengan jarak interval ( $5 \mathrm{~m}$ ). Maka hasilnya adalah sebesar $9,76 \mathrm{~m}^{2}$. Hasil pengamatan dan perhitungan dapat dilihat pada Tabel 5 . Pengukuran luas penampang sungai.

Tabel 5. Pengukuran Luas Penampang Sungai

\begin{tabular}{|c|c|c|c|c|}
\hline $\begin{array}{c}\text { Hari } \\
\text { Ke- }\end{array}$ & $\begin{array}{c}\text { Lebar } \\
\text { Sungai } \\
\text { (meter) }\end{array}$ & $\begin{array}{c}\text { L (Jarak } \\
\text { Interval, } \\
\text { meter) }\end{array}$ & $\begin{array}{c}\text { D (Kedalaman } \\
\text { Basah, meter) }\end{array}$ & $\begin{array}{c}\text { L x D } \\
\left(\mathrm{m}^{2}\right)\end{array}$ \\
\hline $\begin{array}{c}\text { Rata-Rata } \\
\text { Keseluruhan }\end{array}$ & $\mathbf{5}$ & $\mathbf{1 , 9 5}$ & $\mathbf{9 , 7 6}$ \\
\hline
\end{tabular}

\section{Debit air}

Untuk mengetahui debit aliran air dapat dihitung berdasarkan perkalian antara luas penampang vertikal basah sungai dan kecepatan aliran air. Namun demikian, debit yang dihitung ini merupakan debit aliran saat itu (debit sesaat). maka diperoleh hasilnya seperti terlihat pada Tabel 6. Perhitungan debit air

Tabel 6. Perhitungan Debit air

\begin{tabular}{|c|c|c|c|c|}
\hline $\begin{array}{c}\text { Hari } \\
\text { ke- }\end{array}$ & $\begin{array}{c}\text { Tinggi } \\
\text { muka } \\
\text { air (H) } \\
\text { meter }\end{array}$ & $\begin{array}{c}\text { Luas } \\
\text { penampang } \\
\text { basah } \\
\text { sungai (A) }\end{array}$ & $\begin{array}{c}\text { Kecepat } \\
\text { an aliran } \\
\text { (V) m/d }\end{array}$ & $\begin{array}{c}\text { Debit air } \\
\text { (Q) } \mathbf{~ m}^{\mathbf{3} / \mathbf{d}}\end{array}$ \\
\hline 1 & 1,94 & 9,70 & 0,19 & 1,18 \\
\hline 2 & 1,9 & 9,50 & 0,10 & 0,93 \\
\hline 3 & 2,03 & 10,15 & 0,16 & 1,66 \\
\hline 4 & 2,00 & 10,00 & 0,16 & 1,56 \\
\hline 5 & 1,96 & 9,80 & 0,21 & 2,03 \\
\hline 6 & 1,93 & 9,65 & 0,18 & 1,73 \\
\hline 7 & 1,91 & 9,55 & 0,23 & 2,15 \\
\hline $\begin{array}{c}\text { Debit } \\
\text { rata- } \\
\text { rata }\end{array}$ & $\mathbf{1 , 9 5}$ & $\mathbf{9 , 7 6}$ & $\mathbf{0 , 1 7}$ & $\mathbf{1 , 6 9}$ \\
\hline
\end{tabular}

Dari Tabel 6 terlihat bahwa untuk mencari ataupun menghitung debit aliran sungai dapat diketahui dengan menggunakan persamaan 1 sebagai berikut:

$$
\begin{gathered}
Q=A . V \\
Q=9,76 \mathrm{~m}^{2} \times 0,17 \mathrm{~m} / \mathrm{d} \\
Q=1,69 \mathrm{~m}^{3} / \mathrm{d}
\end{gathered}
$$

Jadi hasil perhitungan rata-rata debit aliran sungai dengan cara mengalikan luas penampang basah sungai = $9,76 \mathrm{~m}^{2}$ dengan kecepatan aliran $=0,17 \mathrm{~m} /$ detik. Maka hasil pengukuran debit aliran sungai diperoleh dari pekalian antara luas penampang basah dan kecepatan aliran tersebut adalah $1,63 \mathrm{~m}^{3} /$ detik.

\section{Pengukuran Tinggi Jatuh air}

Pengukuran ini menggunakan sistem google earth dan ketinggian elevasi dari data gambar bendungan. Kondisi medan yang terlalu sulit dan jaraknya cukup jauh. Dalam pengukuran menggunakan data dari Gambar Bendungan maka didapat data ketinggian elevasi Bendungan, data tersebut dapat dilihat pada Tabel 7. Data elevasi ketinggian bendungan.

Tabel 7. Data Elevasi ketinggian bendungan

\begin{tabular}{|c|c|c|}
\hline Elevasi & Data Ketinggian Elevasi & Tinggi Jatuh \\
\hline Elevasi 1 & 333,77 & 3,97 \\
\hline Elevasi 2 & 331,27 & 2,5 \\
\hline Elevasi 3 & 329,8 & 1,47 \\
\hline
\end{tabular}

Dari Tabel 7 terlihat bahwa data elevasi ketinggian bendungan tertinggi terdapat pada data elevasi 1 dengan nilai 333,77 , dan terendah terdapat pada elevasi 3 yaitu 
dengan nilai 329,8. Dari data elevasi ini yang nantinya akan digunakan sebagai data dasar untuk menghitung tinggi jatuh air yang effektif. Namun sebelum menghitung head effectif maka dilakukan terlebih dahulu untuk menghitung rugi ketinggian (head losses) dengan mempertimbangkan faktor koreksi, dan nilai dari faktor koreksi yang digunakan adalah 0,02 . Head loss adalah penurunan tekanan pada fluida yang mengalir didlam pipa, sehingga Perhitungan head losses adalah dengan melihat diameter dari pipa yang digunakan. Pipa yang digunakan dalam penelitian ini adalah pipa PVC yang berdiameter 3 inchi. Maka dari itu hasil perhitungan head loss dapat dilihat pada Tabel 8.

Tabel 8. Hasil perhitungan head losses

\begin{tabular}{|c|c|}
\hline Ukuran Pipa 3 (inchi) & Nilai \\
\hline Panjang (L) meter & 4 \\
\hline Diameter (D) meter & 0,0762 \\
\hline Kecepatan aliran (v) m/det & 0,17 \\
\hline Faktor koreksi & 0,02 \\
\hline Gravitasi & 9,81 \\
\hline Head loss (meter) & 0,001546 \\
\hline
\end{tabular}

Dari Tabel 8 hasil pengukuran dan perhitungan tinggi jatuh air ditentukan dengan ketinggian jatuh air sebenarnya (h) di kurangi dengan head losses (h) terus dengan menggunakan persamaan 5 sebagai berikut:

$$
\begin{aligned}
& H_{l}=0,02 \times \frac{L}{D} \times \frac{v^{2}}{2 \times 9,81} \\
& H_{l}=0,02 \times \frac{4}{0,0762} \times \frac{0,17}{2 \times 9,81} \\
& H_{l}=0,001546 \mathrm{~m}
\end{aligned}
$$

Setelah hasil dari perhitungan head losses sudah diketahui untuk ukuran pipa PVC yang berukuran 3 inchi adalah sebesar 0,001546 meter, jadi untuk perhitungan head effectif untuk masing-masing beda ketinggian dapat dihitung berdasarkan beda elevasi ketinggian, seperti terlihat pada Tabel 9.

Tabel 9. Pengukuran dan perhitungan Head Efektif

\begin{tabular}{|c|c|c|c|}
\multirow{2}{*}{ Pengukuran } & \multicolumn{3}{|c|}{ Nilai } \\
\cline { 2 - 4 } & $\mathbf{1}$ & $\mathbf{2}$ & $\mathbf{3}$ \\
\hline Tinggi jatuh air (h) meter & 3,97 & 2,5 & 1,47 \\
\hline Efisiensi pipa & 0,9 & 0,9 & 0,9 \\
\hline head losses (hloss) meter & 0,002 & 0,002 & 0,002 \\
\hline head efektif (heff) meter & 3,57 & 2,25 & 1,32 \\
\hline
\end{tabular}

Dari Tabel 9 hasil pengukuran dan perhitungan tinggi jatuh air untuk head effectif tertinggi adalah 3,57 meter dan head effectif yang terendah adalah 1,32 meter. Untuk menentukan seberapa besar potensi daya yang bisa terbangkitkan maka hal yang mempengaruhinya adalah debit air dan tinggi jatuhnya air. Oleh sebab itu semakin tinggi jatuh air dan debitnya air yang mengalir pada sungai maka potensi daya yang terbangkitkan akan semakin besar. Hasil dari Head effektif dapat diketahui dengan menggunakan persamaan 4 sebagai berikut:

$$
\begin{aligned}
& H_{l}=H_{a}-H_{l} \times \text { Eff } \\
& H_{l}=3,97-0,002 \times 0,90 \\
& H_{e}=3,57 \mathrm{~m}
\end{aligned}
$$

Jadi untuk perhitungan head effectif untuk masingmasing beda ketinggian didapatkan hasil sebesar 3,57 meter.

\section{Analisa Potensi Daya Terbangkitkan}

Dari hasil perhitungan bahwa besar potensi daya tergantung pada tinggi jatuh air (h) dan debit air (Q). Untuk masing-masing beda tinggi jatuh air dapat terlihat pada Tabel 10 .

Tabel 10. Besar Daya Terbangkitkan

\begin{tabular}{|c|c|c|c|}
\hline $\begin{array}{c}\text { Perhitungan daya } \\
\text { terbangkitkan (ditambah } \\
\text { efisiensi pada pipa) }\end{array}$ & $\mathbf{1}$ & $\mathbf{2}$ & $\mathbf{3}$ \\
\hline Debit air (m3/d) & 1,69 & 1,69 & 1,69 \\
\hline Tinggi terjun air (m) & 3,57 & 2,5 & 1,47 \\
\hline Gravitasi (m/d) & 9,81 & 9,81 & 9,81 \\
\hline Efisiensi pipa & 0,9 & 0,9 & 0,9 \\
\hline Efisiensi turbin & 0,7 & 0,7 & 0,7 \\
\hline Efisiensi generator & 0,8 & 0,8 & 0,8 \\
\hline Daya terbangkitkan (kW) & 29,830 & 20,889 & 12,283 \\
\hline
\end{tabular}

Dari Tabel 10 terlihat bahwa untuk besar potensi daya secara teoritis tergantung pada beda ketinggian tinggi jatuh air. Semakin tinggi titik jatuh air maka beda potensial daya yang terkandung didalam air semakin besar apabila debit airnya tetap ataupun bertambah.

Untuk daya terbangkitkan dapat dihitung dengan menggunakan batas efisiensi terendah dari pipa,turbin dan generator. Efisiensi terendah pada pipa $90 \%$, efisiensi terendah pada turbin $70 \%$, dan efisiensi terendah pada genereator adalah $80 \%$. Perhitungan daya terbangkitkan dapat dihitung dengan menggunakan persamaan 9 sebagai berikut:

$$
\begin{aligned}
& P=Q \times H \times g \times \eta p \times \eta t \times \eta g \\
& P=1,69 \times 3,57 \times 9,81 \times 90 \% \times 70 \% \times 80 \% \\
& P=29,83 k W
\end{aligned}
$$

Jadi potensi daya maksimum yang terbangkitkan adalah sebesar 29,83 $\mathrm{kW}$.

\section{Memilih dan Merancang PLTMH \\ A. Pipa Pesat PVC}

Pipa pesat menggunakan pipa PVC dengan diameter 3 inci $=0,076 \mathrm{~m}$ dan panjang 4 meter. Hasil pengukuran penggunaan pipa dapat dilihat pada Tabel 11.

Tabel 11 Penggunaan Pipa PVC

\begin{tabular}{|c|c|c|c|}
\hline Pipa pesat PVC & Inchi & Nilai & Satuan \\
\hline Panjang & & 4 & $\mathrm{~m}$ \\
\hline Debit air & & 1,69 & $\mathrm{~m} 3 / \mathrm{d}$ \\
\hline Diameter pipa & 3 & 0,076 & $\mathrm{~m}$ \\
\hline Luas penampang pipa & & 0,0046 & $\mathrm{~m} 2$ \\
\hline Kecepatan aliran pada pipa & & 370,77 & $\mathrm{~m} / \mathrm{d}$ \\
\hline
\end{tabular}

Cara menentukan kecepatan pada pipa pesat, hasil pengukuran pada pipa pesat dapat dihitung dengan menggunakan persamaan 6 sebagai berikut:

$$
A=1 / 4 \pi d^{2}
$$




$$
\begin{aligned}
A & =1 / 4 \times 3,14 \times(0,076)^{2} \\
A & =0,0046 \mathrm{~m}^{2} \\
V & =\frac{1,690}{0,0046}=370,77 \mathrm{~m} / \mathrm{d}
\end{aligned}
$$

\section{B. Pipa Pesat Besi}

Pipa pesat menggunakan pipa besi dengan panjang $4 \mathrm{~m}$ yang terbagi menjadi dua ukuran luas penampang yang berbeda. Dengan diameter pipa pesat $\mathrm{D} 1=0,28 \mathrm{~m}$ pada bagian depan dan $\mathrm{D} 2=0,17 \mathrm{~m}$ pada bagian ujung pipa maka kecepatan pipa pesat dapat dilihat pada Tabel 12.

Tabel 12. Penggunaan Pipa Pesat Besi

\begin{tabular}{|c|c|c|}
\hline Pipa pesat besi & Nilai & Satuan \\
\hline Panjang & 4 & $\mathrm{~m}$ \\
\hline Debit air & 1,69 & $\mathrm{~m} 3 / \mathrm{d}$ \\
\hline Diameter 1 & 0,28 & $\mathrm{~m}$ \\
\hline Diameter 2 & 0,17 & $\mathrm{~m}$ \\
\hline Luas penampang 1 & 0,062 & $\mathrm{~m} 2$ \\
\hline Luas penampang 2 & 0,023 & $\mathrm{~m} 2$ \\
\hline Kecepatan aliran dalam pipa 1 & 27,460 & $\mathrm{~m} / \mathrm{d}$ \\
\hline Kecepatan aliran dalam pipa 2 & 74,494 & $\mathrm{~m} / \mathrm{d}$ \\
\hline
\end{tabular}

Hasil perhitungan kecepatan pada saat air melewati pipa besar, dapat dihitung dengan menggunakan persamaan 7 sebagai berikut:

$$
\begin{aligned}
& A_{1}=1 / 4 \times 3,14 \times(0,28)^{2} \\
& A_{1}=0,062 \mathrm{~m}^{2} \\
& V_{1}=\frac{1,69}{0,062} \\
& V_{1}=27,460 \mathrm{~m} / \mathrm{d}
\end{aligned}
$$

Hasil perhitungan kecepatan pada saat air melewati pipa kecil

$$
\begin{aligned}
A_{2} & =1 / 4 \times 3,14 \times(0,17)^{2} \\
A_{2} & =0,023 \mathrm{~m}^{2} \\
V_{2} & =\frac{1,69}{0,023} \\
V_{2} & =74,494 \mathrm{~m} / \mathrm{d}
\end{aligned}
$$

\section{Kincir Air/Turbin}

Berdasarkan spesifikasi teknis kincir air dan mempertimbangkan ketersediaan kincir air yang sudah ada maka dipilih jenis breast-shot sebagai desain peJmbangunan, seperti yang ditunjukkan pada Tabel 13 .

Tabel 13 Spesifikasi Kincir Air

\begin{tabular}{|l|c|c|c|}
\hline Kincir Air/Turbin & m & m/inci & inci \\
\hline Tinggi jatuh air (Inci) & 3,57 & 39,37 & 140,5509 \\
\hline Putaran kincir (rpm) & & 862 & 259,5725 \\
\hline
\end{tabular}

Diketahui tinggi jatuh 3,57 meter $=140,550$ inchi maka dapat dihitung kecepatan putaran kincir air dengan menggunakan persamaan 8 sebagai berikut:

$$
\begin{aligned}
N_{t}=862 \times H^{1 / 2} \\
N_{t}=\frac{862 \times H^{1 / 2}}{D_{1}} \\
N_{t}=\frac{862 \times 140,550^{1 / 2}}{39,37} \\
N_{t}=259,572 \mathrm{rpm}
\end{aligned}
$$

\section{Transmisi Mekanik}

Dilakukan beberapa perhitungan dengan menggunakan satu generator dan satu turbin dengan ukuran diameter pulley adalah $70 \mathrm{~cm}$ dan diameter as $5 \mathrm{~cm}$, hasil perhitungan dapat dilihat perbandingan hasil putaran generator yang didapat seperti terlihat pada Tabel 14 .

Tabel 14. Perbandingan Putaran Generator

\begin{tabular}{|c|c|c|}
\hline $\begin{array}{l}\text { Transmisi } \\
\text { Mekanik }\end{array}$ & $\begin{array}{c}\text { Perbandingan } \\
\text { pulley }\end{array}$ & $\begin{array}{c}\text { Putaran } \\
\text { Generator }\end{array}$ \\
\hline Generator & $11,6663 \mathrm{rpm}$ & $3028,251 \mathrm{rpm}$ \\
\hline
\end{tabular}

\section{E. Generator}

Menggunakan generator sinkron satu phase seri ST-3 dengan kapasitas daya $30 \mathrm{kVA}$. Generator ini memiliki 4 kutup sehingga memerlukan putaran rotor sebesar $1500 \mathrm{rpm}$ untuk membangkitkan energi listrik dengan frekuensi 50 $\mathrm{Hz}$, seperti terlihat pada Tabel 15 .

Tabel 15. Jenis Generator

\begin{tabular}{|c|c|c|}
\hline \multicolumn{3}{|c|}{ Generator Sinkron } \\
\hline Tipe & ST-3 & \\
\hline Jumlah phasa & 1 & Phasa \\
\hline Daya & 3 & $\mathrm{kVa}$ \\
\hline Kecepatan & 1500 & $\mathrm{rpm}$ \\
\hline Jumlah kutub & 4 & Kutub \\
\hline Frekuensi & 50 & $\mathrm{~Hz}$ \\
\hline
\end{tabular}

Berdasarkan data pengukuran dan perhitungan untuk debit air rata-rata yaitu sebesar 1,69 m3/detik dan beda ketinggian tinggi jatuh air yaitu tertinggi 3,57 meter dan terendah 1,32 meter maka didapatkan tenaga potensial air adalah maksimum sebesar $59,187 \mathrm{~kW}$ dan minimum adalah sebesar 24,371 kW. Daya yang terbangkitkan dengan menggunakan batas efisiensi terendah dari pipa, turbin dan generator maka didapat daya terbangkitkan yang maksimum adalah sebesar $29,830 \mathrm{~kW}$ dan minimum adalah sebesar $12,283 \mathrm{~kW}$. Melihat daya yang terbangkitkan tersebut maka potensi air aliran sungai Pinogu secara teknis layak untuk di bangun pembangkit listrik tenaga mikrohidro (PLTMH) dengan kapasitas daya sebesar $30 \mathrm{kVa}$.

\section{KESIMPULAN}

1. Dari hasil pengamatan, pengukuran dan perhitungan maka didapat debit air andalan sebesar 1,69 m3/ detik, dengan luas penampang rata-rata $9,76 \mathrm{~m} 2$ dan kecepatan rata-rata aliran air sebesar $0,173 \mathrm{~m} /$ detik.

2. Dari hasil pengukuran dan perhitungan dengan menggunakan Gambar Bangunan bendungan dan bantuan Google Earth maka didapat beda ketinggian tinggi jatuh air yaitu tinggi maksimum 3,57 meter dan yang tinggi minimum adalah 1,32 meter.

3. Dari hasil perhitungan debit air andalan dan beda tinggi jatuh air maka tenaga potensi air yang dihasilkan adalah maksimum sebesar 59,187 $\mathrm{kW}$ dan minimum adalah sebesar 24,371 kW. Sedangkan daya yang terbangkitkan maksimum adalah $29,83 \mathrm{~kW}$ dan minimum $12,283 \mathrm{~kW}$.

4. Hasil dari debit air andalan, tinggi jatuh air, tenaga potensial air dan daya yang terbangkitkan, maka aliran air sungai Pinogu secara teknis layak untuk dibangun pembangkit tenaga listrik mikrohidro (PLTMH). 


\section{REFERENSI}

[1] BPS. (2018). Kecamatan Pinogu Dalam Angka 2018. (B. P. S. Kabupaten Bone Bolango, Ed.) (2018th ed.). Kabupaten Bone Bolango: BPS Kabupaten Bone Bolango.

[2] Dimyati, A. M. (2003). Studi kelayakan potensi pembangkit listrik tenaga mikrohidro di desa setren kecamatan slogoimo kabupaten wonogiri, 15(02), 1-10.

[3] Doda, N., \& Mohammad, H. (2018). Analisis Potensi Pengembangan Pembangkit Listrik, 1-10.

[4] Fandi S.M. Tambunan \& Rudy Setiabudy. (2014). Feasibility Analysis Of The Development Of Micro Hydro Power ( PLTMH ) In Nyomplong, Bogor mengeluarkan Undang-Undang ( UU ) No . 23 tahun 1997 tentang Pengelolaan pembangunan terhadap lingkungan Melengkapi UU tersebut diterbitkan UU No . 27 Pembangki. Analisis
Kelayakan Pembangunan Pembangkit Listrik Tenaga Mikro Hidro (PLTMH) Di Desa Nyomplong, Bogor, 21.

[5] Firmansyah, I., Mahmudsyah, I. S., \& M.Eng., I. T. yuono. (2008). Studi Pembangunan Pembangkit Listrik Tenaga.

[6] Rizda. (2017). Berbagai Manfaat Pembangkit Listrik Tenaga Mikro Hidro (PLTMH).

[7] Sukamta, S., \& Kusmantoro, A. (2015). Perencanaan pembangkit listrik tenaga mikro hidro (PLTMH) Jantur Tabalas Kalimantan Timur. Jurnal Teknik Elektro, 5(2), 58-63. https://doi.org/10.1016/j.bej.2007.02.031.

[8] Suparman, Suyono, H., \& Hasanah, R. N. (2017). Desain Pembangkit Listrik Tenaga Piko Hidro Terapung (PLTPHT), 11(2), 82-88. 